\title{
Pembelajaran Fisika Berbasis Literasi Sains terhadap Penguasaan Konsep Mahasiswa pada Pokok Bahasan Energi
}

\author{
Nira Nurwulandari ${ }^{(1)}$ \\ ${ }^{1}$ Universitas Nahdlatul Ulama Blitar \\ Email: ${ }^{1}$ nirra.nrwd@gmail.com, \\ DOI: https://doi.org/10.28926/riset_konseptual.v2i2.51
}

\begin{abstract}
ABSTRAK
Penelitian ini bertujuan untuk mengetahui pengaruh Pembelajaran Fisika Berbasis Literasi Sains terhadap Penguasaan Konsep Mahasiswa Pada Pokok Bahasan Energi. Desain penelitian yang digunakan adalah one-shot case study, dengan populasi seluruh mahasiswa PGSD semester ganjil angkatan 2017/2018 Universitas Nahdlatul Ulama Blitar. Sampel penelitian adalah mahasiswa PGSD C yang diambil dengan teknik Cluster Random Sampling. Berdasarkan hasil uji regresi linier sederhana diperoleh kesimpulan bahwa terdapat pengaruh positif dan signifikan antara Pembelajaran Fisika Berbasis Literasi Sains terhadap Penguasaan Konsep Mahasiswa Pada Pokok Bahasan Energi sebesar 54,61 \%. Penguasaan Konsep Mahasiswa dan Pembelajaran Fisika Berbasis Literasi Sains memiliki hubungan yang kuat dan berkontribusi positif.
\end{abstract}

Kata kunci: literasi sains, penguasaan konsep, fisika, energy,

\section{PENDAHULUAN}

Pembelajatan fisika dapat diartikan sebagai proses pembelajaran fenomenafenomena alam. Pada pembelajaran fisika, keberhasilan pembelajaran dapat diukur dengan mengetahui kemampuan penguasaan konsep mahasiswa. Menurut Arikunto (2010: 115) mahasiswa dikatakan memiliki pemahaman (comprehension) atau penguasaan konsep yang baik jika mereka memahami hubungan yang sederhana antara fakta-fakta atau konsep serta dapat menyajikan ulang konsep tersebut kedalam bentuk yang lain. Hal ini menunjukkan bahwa pembelajaran fisika merupakan pembelajaran yang menuntut penguasaan dan aplikasi agar terjadi keberhasilan dalam pembelajaran fisika. Dengan demikian, dalam pembelajaran fisika mahasiswa dituntut agar berperan aktif dalam membangun pengetahuan dan penguasaan konsep dalam diri mereka sendiri. Salah satu cara memahami hubungan yang sederhana antara fakta-fakta atau konsep adalah dengan pembelajaran fisika berbasis literasi sains. Pembelajaran fisika berbasis literasi sains merupakan pembelajaran fisika dengan menghubungkan sains dalam kehidupan sehari-hari.

Kebanyakan mahasiswa mengalami kesulitan mengaplikasikan perannya dalam proses pembelajaran dikarenakan rendahnya penguasaan konsep fisika yang dimilikinya. Kurangnya kemampuan mahasiswa dalam memahami konsep yang dimiliki menyebabkan rendahnya hasil belajar. Untuk meningkatkan penguasaan konsep tersebut, Dosen perlu meningkatkan kualitas pembelajaran di kelas dengan menggunakan variasi metode dan media pembelajaran yang tepat. Adapun metode pembelajaran yang bisa digunakan adalah dengan pembelajaran fisika berbasis literasi sains.

Pembelajaran ini berfokus pada 4 aspek literasi sains, yaitu sains sebagai batang tubuh pengetahuan, sains sebagai cara untuk menyelidiki, sains sebagai cara berpikir, serta interaksi sains, teknologi, dan masyarakat. Pada aspek pertama sains sebagai batang tubuh pengetahuan ini menjelaskan fakta, konsep, teori, hukum, 
prinsip pada bab usaha dan energi. Pada aspek ini juga menyajikan informasi yang terkait dengan fenomena dalam kehidupan sehari-hari. Informasi ini bisa berupa gambar gambar/percakapan.

Pada aspek kedua sains sebagai cara untuk menyelidiki ini menyajikan beberapa eksperimen yang mengharuskan mahasiswa terlibat di dalamnya. Pada eksperimen ini mahasiswa melakukan perconaan dengan prosedur yang ada, mencatat data hasil pengamatan, melakukan analisis, menjawab pertanyaan berdasarkan data yang diperoleh, dan menarik kesimpulan. Pada aspek ketiga sains sebagai cara berpikir ini berisi tentang cerita seorang ilmuwan menemukan teorinya dimulai dengan mengembangkan sebuah ide dan gambaran bagaimana la melakukan eksperimen.

Aspek literasi sains yang keempat yaitu interaksi sains, teknologi, dan masyarakat ini menjelaskan aplikasi yang berhubungan dengan bab Usaha dan Energi beserta manfaat dan dampak negatif yang ditimbulkan terhadap kehidupan. Dari dampak tersebut bisa juga menimbulkan masalah-masalah sosial yang terjadi dalam kehidupan bermasyarakat. Selain itu, disajikan pula karir atau pekerjaan yang berkaitan dengan aplikasinya. Fitur ini memberikan contoh aplikasi, seperti televisi, PLTU, PLTA, dan PLTD. Dari masing-masing contoh aplikasi yang telah diuraikan, mahasiswa diharapkan menjadi lebih luas pengetahuannya sehingga tidak hanya memahami secara teori.

Tujuan penelitian ini adalah untuk mendeskripsikan pembelajaran fisika berbasis literasi sains di UNU Blitar, pengaruh pembelajaran fisika berbasis literasi sains terhadap penguasaan konsep mahasiswa, dan mendeskripsikan peningkatan penguasaan konsep fisika mahasiswa dengan pembelajaran fisika berbasis literasi sains.

\section{METODE}

Penelitian ini merupakan studi eksperimen dengan populasi penelitian yaitu seluruh mahasiswa PGSD semester ganjil angkatan 2017/2018 Universitas Nahdlatul Ulama Blitar. Sampel penelitian ini adalah mahasiswa PGSD C yang diambil dengan teknik Cluster Random Sampling. Teknik cluster random sampling adalah teknik pengambilan sampel dengan cara mengundi dari empat kelas PGSD yang ada di UNU Blitar. Berdasarkan populasi yang terdiri dari 4 kelas diambil 1 kelas secara acak sebagai sampel. Sampel yang diperoleh adalah kelas PGSD C sebagai sampel penelitian.

Jenis penelitian ini adalah penelitian eksperimen dengan One-shot-CaseStudy. Pembelajaran fisika berbasis literasi sains terhadap penguasaan konsep fisika mahasiswa diukur menggunaka desain penelitian One-shot-Case-Study. Desain ini digunakan dalam satu kelompok dengan pemberian satu kali perlakuan dan pengukurannya dilakukan satu kali (Sudjana, 2005).

. Kegiatan pembelajaran diawali dengan pre-test untuk mengukur kemampuan awal mahasiswa kemudian pada akhir pembelajaran Dosen memberikan posttest dan penilaian kemampuan literasi sains. Kemudian nilai kemampuan literasi sains dikorelasikan dengan penguasaan konsep fisika mahasiswa, dan nilai pretest-posttest dilakukan uji paired sample $t$-test untuk mengetahui peningkatan penguasaan konsep fisika. Secara umum desain penelitian ditunjukkan pada gambar 1.

$$
\mathrm{X} \quad \mathrm{O}
$$

\section{Gambar 1. Desain Eksperimen}

Pada penelitian ini terdapat dua variabel, yaitu variabel bebas dan terikat. Variabel bebas dalam penelitian ini adalah pembelajaran fisika berbasis literasi sains, sedangkan variabel terikatnya adalah penguasaan konsep fisika mahasiswa. 
Instrumen yang digunakan dalam penelitian ini adalah Silabus Pembelajaran, Rencana Pelaksanaan Pembelajaran (RPP), Instrumen tes kemampuan literasi sains dan penguasaan konsep fisika mahasiswa. Sebelum instrumen digunakan dalam sampel, instrumen diuji terlebih dahulu dengan menggunakan uji validitas dan uji reliabilitas dengan menggunakan program SPSS versi 22.0. Data yang telah diperoleh kemudian dianalisis menggunakan beberapa macam uji yaitu uji normalitas, uji linearitas, uji korelasi, dan uji regresi linear sederhana.

\section{HASIL}

Penelitian mengenai pengaruh pembelajaran fisika berbasis literasi sains terhadap penguasaan konsep fisika mahasiswa ini mulai dilaksanakan pada hari Jumat tanggal 2 Desember 2017 di UNU Blitar. Proses pembelajaran berlangsung selama 3 kali tatap muka dengan alokasi waktu 2 jam pelajaran yang terdiri atas 50 menit per jam pelajaran. Pada penelitian ini diperoleh hasil berupa data kuantitatif yang selanjutnya diolah dengan menggunakan program SPSS versi 22.0.

Kelas yang digunakan sebagai penelitian adalah kelas PGSD C UNU Blitar. Semua kegiatan pembelajaran berlangsung di dalam ruang kelas. Adapun Pelaksanaan pembelajaran di kelas ini diikuti oleh 30 siswa dan dilakukan menyesuaikan jadwal mata kuliah Konsep Dasar Sains 1 di UNU Blitar pada hari Jumat pukul 15.15 WIB sampai dengan 17.15 WIB.

\section{Data N-Gain}

Penelitian ini pada aspek penguasaan konsep fisika mahasiswa yang dinilai sebanyak dua kali, yaitu untuk mengetahui kemampuan awal dan akhir penguasaan konsep mahasiswa. Pada penelitian ini diperoleh data sebanyak 19 mahasiswa memiliki N-Gain dalam kategori tinggi, sebanyak 11 mahasiswa memiliki N-Gain dalam kategori sedang, dan sebanyak 0 mahasiswa memiliki N-Gain dalam kategori rendah.

Berdasarkan keseluruhan tersebut yang diperoleh, dapat dikatakan bahwa mahasiswa PGSD C UNU Blitar mengalami peningkatan penguasaan konsep. Nilai $\mathrm{N}$ Gain dapat dilihat pada gambar 2 berikut.

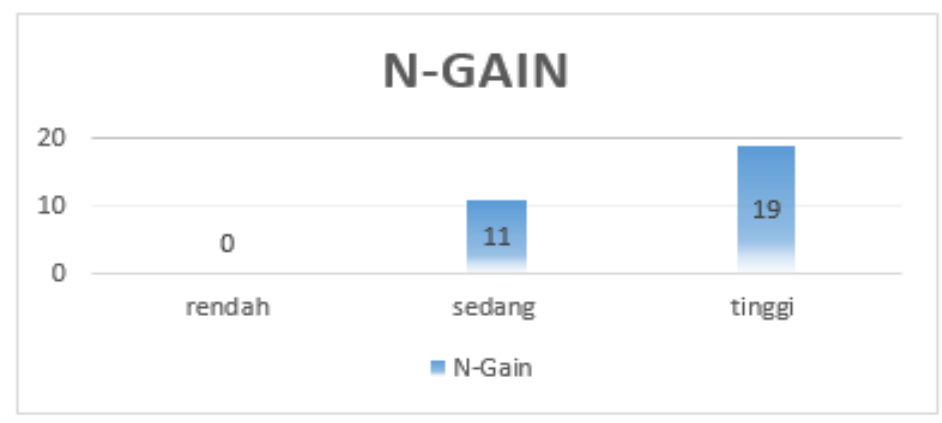

Gambar 2. Nilai N-Gain

Uji Normalitas Data

Berdasarkan uji normalitas dengan menggunakan SPSS 22.0 diperoleh sig. untuk data kemampuan literasi sains dan penguasaan konsep mahasiswa ditunjukkan oleh tabel 1 berikut.

Tabel 1. Hasil Uji normalitas data kemampuan literasi sains dan penguasaan konsep mahasiswa

\begin{tabular}{|l|l|l|}
\hline \multicolumn{1}{|c|}{ Tes } & Sig. & Ket. \\
\hline Pretest Kemampuan literasi sains & 0,203 & Normal \\
$\begin{array}{l}\text { Pretest Penguasaan konsep } \\
\text { mahasiswa }\end{array}$ & 0,074 & Normal \\
\hline
\end{tabular}


Vol. 2 No. 2, April 2018;

Berdasarkan data yang disajikan pada pada table dapat diketahui bahwa jumlah mahasiswa sebanyak 30 orang, dan nilai Shapiro-Wilk p pada pre-test kemampuan literasi sains dan penguasaan konsep yaitu 0,074 dan 0,203 diatas 0,05. Data akan memiliki distribusi normal jika $p \geq 0,05$. Berdasarkan hasil uji tersebut dapat disimpulkan bahwa data kemampuan literasi sains dan penguasaan konsep mahasiswa terdistribusi normal.

\section{Uji linearitas}

Uji linearitas dilakukan untuk mengetahui apakah dua variable mempunyai hubungan yang linear atau tidak secara signifikan. Uji linearitas menggunakan program SPSS 22 dengan metode Text for Linearity pada taraf signifikansi atau Sig. sebesar 0,05 . Hasil analisis data uji linearitas ditunjukkan oleh tabel 2 berikut.

\section{Tabel 2. Hasil Uji linearitas kemampuan literasi sains dan penguasaan konsep}

\begin{tabular}{|l|l|l|}
\hline \multicolumn{1}{|c|}{ Tes } & Sig. & Ket. \\
\hline $\begin{array}{l}\text { Kemampuan literasi sains - } \\
\text { Penguasaan konsep mahasiswa }\end{array}$ & 0,046 & Linier \\
\hline
\end{tabular}

Berdasarkan data yang disajikan maka dapat dilihat bahwa nilai signigikansi linearity sebesar 0,046 . Nilai tersebut kurang dari 0,05 sehinga dapat disimpulkan bahwa hubungan antara literasi sains dan penguasaan konsep adalah linier.

\section{Uji korelasi}

Uji korelasi bertujuan untuk melihat derajad keeratan hubungan dan arah hubungan serta mencari koefisien determinasi yang berfungsi untuk melihat seberapa besar kontribusi pembelajaran fisika berbasis literasi sains terhadap penguasaan konsep fisika mahasiswa. Jika data terdistribusi normal maka untuk menguji hipotesis menggunakan uji pearson. Uji korelasi dilakukan dengan bantuan program SPSS 22 dimana hasil pembacaan tabel correlation dapat dilihat pada tabel 3 berikut.

Tabel 3. Hasil Uji korelasi kemampuan literasi sains dan penguasaan konsep

\begin{tabular}{|l|c|l|}
\hline \multicolumn{1}{|c|}{ Tes } & r hitung & Sig. \\
\hline $\begin{array}{l}\text { Kemampuan literasi sains - } \\
\text { Penguasaan konsep } \\
\text { mahasiswa }\end{array}$ & 0,739 & 0,000 \\
\hline
\end{tabular}

Berdasarkan tabel di atas dapat diketahui bahwa nilai Pearson $r$ sebesar 0,739 dengan sig. (2-tailed) sebesar 0,000 atau lebih kecil dari 0,05 sehingga diputuskan bahwa pembelajaran fisika berbasis literasi sains terhadap penguasaan konsep fisika mahasiswa berhubungan nyata dan signifikan.

Berdasarkan Tabel 3 dapat dihitung besar koefisien determinasi dengan cara mengkuadratkan nilai hitung lalu mengkonversikannya ke dalam persentase seperti tabel 4 berikut.

Tabel 4. Hasil koefisien determinasi data kemampuan literasi sains dan penguasaan konsep fisika mahasiswa

\begin{tabular}{|l|c|c|}
\hline \multicolumn{1}{|c|}{ Data } & $\begin{array}{c}\mathrm{r} \\
\text { hitung }\end{array}$ & $\begin{array}{l}\text { Koefisien } \\
\text { determinasi }\end{array}$ \\
\hline $\begin{array}{l}\text { Kemampuan literasi sains - } \\
\text { Penguasaan konsep } \\
\text { mahasiswa }\end{array}$ & 0,739 & $54,61 \%$ \\
\hline
\end{tabular}




\section{Uji regresi linier sederhana}

Pengujian hipotesis yang pertama adalah uji regresi linier sederhana. Uji regresi linier sederhana digunakan untuk memprediksi nilai dari variabel terikat apabila nilai variabel bebas $(X)$ mengalami kenaikan atau penurunan dan untuk mengetahui hubungan antara variabel bebas $(\mathrm{X})$ dengan variabel terikat $(\mathrm{Y})$ apakah positif atau negative. Hasil analisis uji regresi linier sederhana didapat data pada tabel coefficients untuk memperoleh konstanta a dan b seperti pada tabel 5 berikut.

\section{Tabel 5. Hasil Uji regresi sederhana data kemampuan literasi sains dan penguasaan konsep fisika mahasiswa}

\begin{tabular}{|l|c|c|c|}
\hline \multicolumn{1}{|c|}{ Hasil belajar (Y) } & & $\begin{array}{c}\mathrm{t} \\
\text { hitung }\end{array}$ & Sig. \\
\hline Konstanta & 16,637 & 1,881 & 0,003 \\
Kemampuan literasi sains $(\mathrm{X})$ & 0,830 & 5,805 & 0,000 \\
\hline
\end{tabular}

Hasil uji regresi linier sederhana pada tabel 5 didapat nilai konstanta (a) sebesar 16,637 dan nilai konstanta (b) sebesar 0,830. Persamaan regresi linier sederhana seperti berikut.

$$
Y=a+b X=16,637+0,830 X
$$

Pada Tabel 5 diperoleh nilai t tabel untuk df $=28$ adalah 1,881 dengan taraf signifikansi sebesar 0,05, maka diperoleh keputusan bahwa nilai t hitung untuk koefisien $\alpha$ sebesar 1,881 (bernilai positif) lebih besar dari nilai tabel $(28 ; 0,05)(1,701)$ dan Sig. $(0,003)$ lebih kecil dari $(0,05)$, sehingga dapat dinyatakan bahwa koefisien signifikan. Sedangkan, nilai hitung untuk koefisien sebesar 5,805 (bernilai positif) lebih besar dari nilai tabel $(28 ; 0,05)(1,701)$ dan Sig. $(0,000)$ lebih kecil dari $(0,05)$, sehingga dapat dinyatakan bahwa koefisien juga signifikan.

Hasil uji regresi untuk pengaruh pembelajaran fisika berbasis literasi sains terhadap penguasaan konsep fisika mahasiswa dengan menggunakan program komputer SPSS 21.0 diperoleh hasil dari hitung, F hitung dan nilai Sig menunjukkan bahwa nilai hitung dan $\mathrm{F}$ hitung bernilai positif, nilai Sig yang diperoleh lebih kecil dari $(0,05)$, sehingga dapat disimpulkan Ho ditolak dan $\mathrm{H} 1$ diterima yang berarti terdapat pengaruh yang positif dan signifikan antara pembelajaran fisika berbasis literasi sains terhadap penguasaan konsep fisika mahasiswa.

\section{Uji Paired Sample T-Test}

Uji paired sample $t$-test adalah analisis dengan melibatkan dua pengukuran pada subyek yang sama terhadap suatu pengaruh atau perlakuan tertentu. Uji paired sample t-test dilakukan dengan menggunakan bantuan program SPSS 22 dimana pada uji ini akan terlihat perbedaan rata-rata penguasaan konsep sebelum dan sesudah diberikan perlakuan berupa pembelajaran fisika berbasis literasi sains, peningkatan dan penurunan rata-rata penguasaan konsep mahasiswa, serta peningkatan dan penurunan secara signifikan terhadap data hasil pre-test dan posttest. Hasil analisis uji paired sample t-test pada tabel 6 berikut.

Tabel 6. Hasil Uji paired sample t-test data pretest dan posttest penguasaan konsep fisika mahasiswa

\begin{tabular}{|l|c|c|c|c|c|}
\hline \multicolumn{1}{|c|}{ Tes } & $\begin{array}{c}\text { Rata-rata } \\
\text { (mean) }\end{array}$ & $\begin{array}{c}\text { Perbedaan rata- } \\
\text { rata (mean) }\end{array}$ & Korelasi & t hitung & Sig. \\
\hline $\begin{array}{l}\text { Pretest } \\
\text { Posttest }\end{array}$ & 20,73 & 57,567 & 0,437 & 52,719 & 0,000 \\
\hline
\end{tabular}


Dari tabel 6 terlihat bahwa rata-rata penguasaan konsep mahasiswa meningkat dari 20,73 menjadi 78,30 . Perbedaan rata-rata data hasil pre-test dan posttest penguasaan konsep mahasiswa sebesar 57,567. Dari tabel paired sample correlation terlihat bahwa korelasi antara pre-test dan post-test sebesar 0,437 dalam kategori sedang. Pada tabel di atas terlihat juga nilai sig. (2-tailed) $=0,000<0,05$. Kesimpulan berdasarkan hasil analisis uji paired sample t-test bahwa terdapat peningkatan secara signifikan penguasaan konsep mahasiswa akibat pengaruh pembelajaran fisika berbasis literasi sains.

Berdasarkan hasil analisis metode pengujian hipotesis bahwa $\mathrm{HO}$ ditolak dan $\mathrm{H} 1$ diterima, artinya terdapat peningkatan penguasaan konsep secara siginifikan akibat pengaruh pembelajaran fisika berbasis literasi sains.

\section{PEMBAHASAN \\ Pembelajaran Fisika Berbasis Literasi Sains di UNU Blitar}

Pembelajaran fisika yang diberikan kepada mahasiswa adalah pembelajaran berbasis literasi sains pada tema aplikasi konep energi dalam kehidupan. Pembelajaran ini berfokus pada 4 aspek literasi sains, yaitu sains sebagai batang tubuh pengetahuan, sains sebagai cara untuk menyelidiki, sains sebagai cara berpikir, serta interaksi sains, teknologi, dan masyarakat. Pada aspek pertama sains sebagai batang tubuh pengetahuan ini menjelaskan fakta, konsep, teori, hukum, prinsip pada bab usaha dan energi. Pada aspek ini juga menyajikan informasi yang terkait dengan fenomena dalam kehidupan sehari-hari. Informasi ini bisa berupa gambar/percakapan. Pada aspek kedua sains sebagai cara untuk menyelidiki ini menyajikan beberapa eksperimen yang mengharuskan mahasiswa terlibat di dalamnya. Pada eksperimen ini mahasiswa melakukan perconaan dengan prosedur yang ada, mencatat data hasil pengamatan, melakukan analisis, menjawab pertanyaan berdasarkan data yang diperoleh, dan menarik kesimpulan. Pada aspek ketiga sains sebagai cara berpikir ini berisi tentang cerita seorang ilmuwan menemukan teorinya dimulai dengan mengembangkan sebuah ide dan gambaran bagaimana la melakukan eksperimen.

Aspek literasi sains yang keempat yaitu interaksi sains, teknologi, dan masyarakat ini menjelaskan aplikasi yang berhubungan dengan bab Usaha dan Energi beserta manfaat dan dampak negative yang ditimbulkan terhadap kehidupan. Dari dampak tersebut bisa juga menimbulkan masalah-masalah sosial yang terjadi dalam kehidupan bermasyarakat. Selain itu, disajikan pula karir atau pekerjaan yang berkaitan dengan aplikasinya. Fitur ini memberikan contoh aplikasi, seperti televisi, Pembangkit Listrik Tenaga Uap (PLTU), Pembangkit Listrik Tenaga Air (PLTA), Pembangkit Listrik Tenaga Diesel (PLTD), dan Pembangkit Listrik Tenaga Angin. Dari masing-masing contoh aplikasi yang telah diuraikan, mahasiswa diharapkan menjadi lebih luas pengetahuannya sehingga tidak hanya memahami secara teori.

Ketika pembelajaran konsep energi Dosen memberikan pembelajaran berbasis literasi sains. Dari proses pembelajaran menunjukkan bahwa mahasiswa sebagian besar mampu menjawab pertanyaan dalam Lembar Kerja (LK). Hal ini terlihat dari cara mahasiswa memahami pertanyaan dan mampu menjawabnya dengan benar. Dalam memahami pertanyaan dan menjawabnya, mahasiswa sebagian besar tidak perlu dituntun untuk menyelesai-kannya. Dari proses pembelajaran menunjukkan bahwa mahasiswa mampu belajar fisika berbasis literasi sains. Hasil kemampuan literasi sains dapat dilihat paga gambar 2 . 


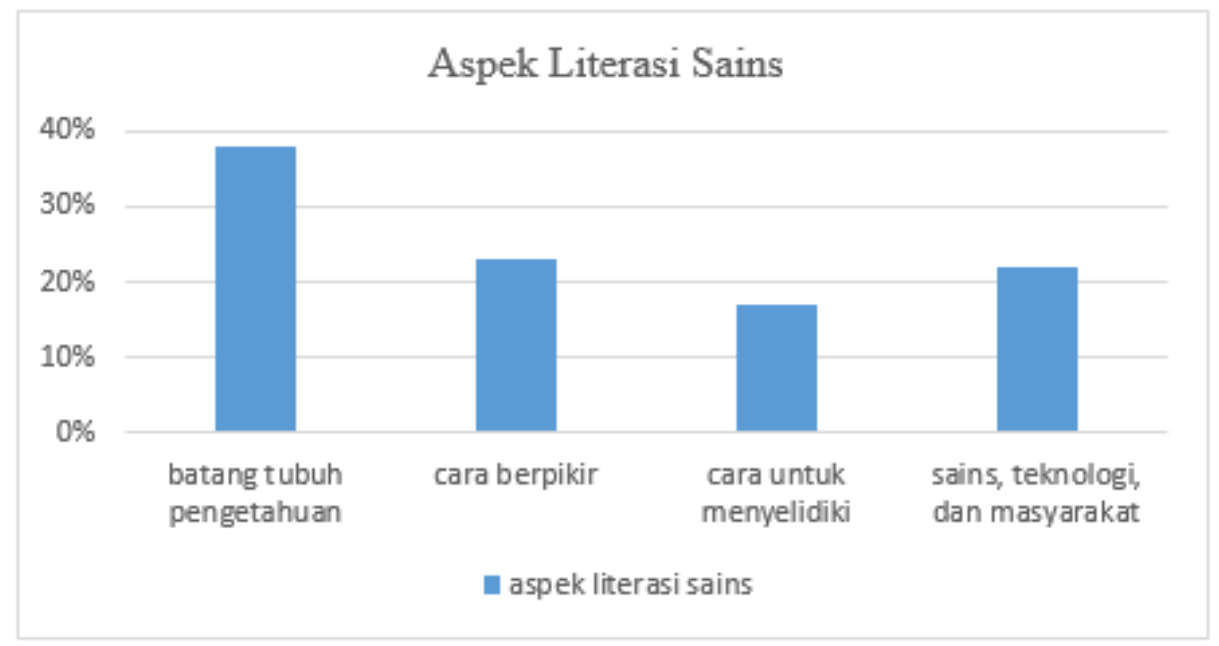

\section{Gambar 2. Kemampuan Tiap Aspek Literasi Sains}

Aspek literasi sains tertinggi adalah sains sebagai batang tubuh pengetahuan, peringkat kedua adalah sains sebagai cara untuk berpikir, peringkat ketiga adalah interaksi sains, teknologi dan masyarakat, dan yang terendah adalah sains sebagai cara untuk menyelidiki. Aspek literasi sains yang paling tinggi adalah sains sebagai batang tubuh pengetahuan. Hasil analisis tersebut mencerminkan bahwa pembelajaran fisika lebih menekankan pada konsep/teori. Hasil ini sesuai dengan penelitian yang dilakukan Maturradiyah, N \& A. Rusilowati (2015) tentang analisis buku ajar fisika SMA di kabupaten Pati berdasarkan muatan literasi sains. Penelitian tersebut menunjukkan bahwa buku ajar yang beredar banyak mengandung pengetahuan, sedangkan aktivitas berpikir, menyelidiki dan interaksi sains, teknologi dan masyarakat sangat sedikit.

Aspek interaksi sains, teknologi dan masyarakat yang menempati posisi ketiga dengan persentase $22 \%$ menunjukkan bahwa mahasiswa memiliki keterampilan menggunakan sains pada peristiwa dalam kehidupan sehari-hari. Hasil ini sesuai dengan penelitian Agustini (2013) yang menyatakan bahwa model pembelajaran sains, teknologi dan masyarakat dapat meningkatkan keterampilan pemecahan masalah IPA dalam kehidupan sehari-hari. American National Science Teachers Association (NSTA) juga menyatakan bahwa interaksi antara sains, teknologi dan masyarakat menjadi dasar pendidikan sains karena pentingnya mengajarkan hubungan interaktif antara ilmu pengetahuan, teknologi dan masyarakat dalam pengambilan keputusan pada masalah sehari-hari (Mansour, 2009).

Kemampuan siswa pada aspek sains sebagai cara berpikir tergolong tinggi karena soal-soal latihan yang terdapat pada Lembar Kerja yang digunakan lebih banyak meminta mahasiswa untuk menganaslisis soal berdasarkan fenomena dalam kehidupan sehari-hari. Selain itu soal-soal yang diberikan banyak membutuhkan penggunaan konsep sehingga kemampuan berpikir mahasiswa cukup tinggi. Hal ini sesuai dengan penelitian Eggen (2012:110) yang menyatakan bahwa semakin sering siswa belajar tentang satu topik, semakin baik mereka mampu berpikir tentang topik itu. Dengan demikian, semakin sering mahasiswa dihadapkan pada soal analisis dan penggunaan konsep maka semakin baik pula kemampuan mereka.

\section{Pembelajaran Fisika Berbasis Literasi Sains Terhadap Penguasaan Konsep Mahasiswa}

Penelitian yang telah dilakukan bertujuan untuk menjawab rumusan masalah yang ada, yakni apakah terdapat pengaruh linear yang positif dan signifikan antara pembelajaran fisika berbasis literasi sains terhadap penguasaan konsep mahasiswa. Hasil uji linier sederhana menyimpulkan HO ditolak. Artinya, terdapat pengaruh linear yang positif dan signifikan antara pembelajaran fisika berbasis literasi sains terhadap 
penguasaan konsep mahasiswa. Besarnya pengaruh linear yang positif dan signifikan antara pembelajaran fisika berbasis literasi sains terhadap penguasaan konsep mahasiswa. Besarnya pengaruh linear yang positif dan signifikan antara pembelajaran fisika berbasis literasi sains terhadap penguasaan konsep mahasiswa dilihat dari nilai determinasi (R square) yaitu 0,739 atau 54,61\%.

Selain itu, analisis pembelajaran fisika berbasis literasi sains berpengaruh terhadap peningkatan atau penurunan penguasaan konsep mahasiswa dapat menggunakan persamaan regresi linier sederhana $Y=a+b x=16,637+0,830 x$, artinya jika pembelajaran fisika berbasis literasi sains $(x)$ sebesar 0 , maka penguasaan konsep mahasiswa sebesar 16,637. Jika pembelajaran fisika berbasis literasi sains $(x)$ sebesar 1, maka penguasaan konsep mahasiswa sebesar 17,467. Peningkatan penguasaan konsep itu sendiri hanya mengalami kenaikan sebesar 0,830.

Kemampuan mahasiswa dalam menganalisis fenomena dalam kehidupan sehari-hari erat kaitannya dengan aspek pengetahuan sains yang mereka pahami terkait konsep energi. Pertanyaan analisis pada butir soal literasi menghubungkan aspek kognitif mahasiswa dengan fenomena yang biasa ditemui dalam kehidupannya. Berdasarkan teori pembelajaran kognitif, mahasiswa menggunakan pengetahuan awalnya untuk memproses informasi baru dengan menghubungkan informasi baru tersebut dengan pengetahuan awal yang dimilikinya (Lyle \& Robinson, 2001). Kadar aspek kognitif yang terdapat pada memori mahasiswa berpengaruh terhadap kemampuan mahasiswa dalam menganalisis fenomena dalam kehidupan sehari-hari. Sedangkan penguasaan konsep merupakan kegiatan yang berhubungan dengan ranah kognitif yang sesuai dengan klasifikasi Bloom, yaitu pengetahuan, pemahaman, penerapan, analisis, sintesis, dan evaluasi.

\section{Pengaruh Pembelajaran Fisika Berbasis Literasi Sains Terhadap Penguasaan Konsep Mahasiswa}

Berdasarkan hasil analisis pada uji Independent Sample T-test maka dapat disampaikan bahwa ada perbedaan rata-rata penguasaan konsep mahasiswa menggunakan pembelajaran fisika berbasis literasi sains. Hal ini terlihat data kuantitatif yang menunjukkan pembelajaran dengan menggunakan pembelajaran fisika berbasis literasi sains meningkatkan kemampuan penguasaan konsep mahasiswa.

Berdasarkan nilai rata-rata penguasaan konsep tersebut, membuktikan bahwa nilai post-test penguasaan konsep mahasiswa pada kelas eksperimen lebih baik dibandingkan nilai pre-test nya. Sesuai dengan gambar di atas terdapat 11 mahasiswa yang mempunyai $\mathrm{N}$-gain sedang, 19 mahasiswa yang mempunyai $\mathrm{N}$-gain tinggi, dan tidak ada mahasiswa yang memiliki $N$-gain rendah. Perbedaan mendasar kedua nilai tersebut mengindikasikan bahwa ada pengaruh signifikan dengan pembelajaran fisika berbasis literasi sains terhadap penguasaan konsep fisika mahasiswa.

Penguasaan konsep terhadap pembelajaran fisika berbasis literasi sains dipengaruhi oleh beberapa faktor antara lain pendekatan atau metode pembelajaran sains yang digunakan oleh Dosen dalam membangun konsep pembelajaran. Pembelajaran yang mampu membangkitkan rasa ingin tahu mahasiswa terkait topik pembelajaran dan mendorong semangat mahasiswa untuk memecahkan masalah yang disajikan Dosen diyakini mampu membangun keterampilan proses sains yang merupakan bagian dari aspek kompetensi literasi sains. Kemampuan literasi sains juga mencakup kemampuan dalam memahami Nature of Science yang sejalan dengan konsep keterampilan inkuiri sains seperti merancang percobaan, mengumpulkan dan menganalisis data, dan menggambar kesimpulan yang ditarik berdasarkan bukti ilmiah (Mc. Donald \& Dominguez dalam Salamon, 2007).

\section{KESIMPULAN}

Pembelajaran fisika berbasis literasi sains di UNU Blitar pada tema aplikasi konep energi dalam kehidupan. Pembelajaran ini berfokus pada 4 aspek literasi sains, yaitu sains sebagai batang tubuh pengetahuan, sains sebagai cara untuk menyelidiki, 
sains sebagai cara berpikir, serta interaksi sains, teknologi, dan masyarakat. Aspek literasi sains tertinggi adalah sains sebagai batang tubuh pengetahuan, peringkat kedua adalah sains sebagai cara untuk berpikir, peringkat ketiga adalah interaksi sains, teknologi dan masyarakat, dan yang terendah adalah sains sebagai cara untuk menyelidiki. Terdapat pengaruh linear yang positif dan signifikan antara pembelajaran fisika berbasis literasi sains terhadap penguasaan konsep fisika mahasiswa. Besarnya pengaruh linear yang positif dan signifikan antara pembelajaran fisika berbasis literasi sains terhadap penguasaan konsep mahasiswa sebesar 54,61\%. Terdapat peningkatan penguasaan konsep fisika mahasiswa yang signifikan disebabkan oleh pengaruh pembelajaran fisika berbasis literasi sains seberar 57,567 dengan $\mathrm{N}$-Gain rata-rata penguasaan konsep sebesar 0,437 dengan kategori sedang.

\section{SARAN}

Dosen sebaiknya dalam pembelajaran fisika yang melibatkan banyak penguasaan konsep bukan penghafalan materi, menemukan dan menggunakana metode yang sesuai dengan kondisi siswa agar materi yang disampaikan dapat dipahami. Sebaiknya Dosen sudah menyiapkan strategi atau metode pembelajaran yang tepat, meliputi persiapan mengajar seperti pembuatan RPP, media, metode belajar, Lembar Kerja dan sebagainya sebelum pembelajaran dimulai. Pembelajaran fisika berbasis literasi sains berpengaruh terhadap penguasaan konsep mahasiswa pada pokok bahasan energi. Peneliti lain bisa melakukan pembelajaran serupa untuk materi fisika yang lain dengan perencanaan yang lebih baik.

\section{DAFTAR RUJUKAN}

Arikunto, Suharsimi. 2010. Evaluasi Program Pembelajan. Jakarta: Bumi Aksara Desmita. 2015. Psikologi Perkembangan. Bandung: PT. Remaja Rosdakarya.

Eggen, P \& D. Kauchak. 2012. Strategi dan Model Pembelajaran: Mengajarkan Konten dan Keterampilan Berpikir. Diterjemahkan oleh Satrio Wahono. 2012. Jakarta: Indeks.

Lyle, K., and Robinson, W. 2001. Teaching Science Problem Solving: An Overview of Experimental Work. Journal of Chemical Eduction. 78 (9): 1162-1165.

Mansour, N. 2009. Science-Technology-Society (STS): A new paradigm in Science Education. Bulletin of science, technology and society. 29(4): 287-297.

Maturradiyah, N. \& A. Rusilowati. 2015. Analisis Buku Ajar Fisika SMA Kelas XII di Kabupaten Pati Berdasarkan Muatan Literasi Sains. Unnes Physics Education Journal, 4(1):16-20.

Salamon. 2007. Scientific Literacy in Higher Education. Tamarat Teaching Professorshing: University of Calgary.

Sudjana. 2005. Metode Statistika (edisi 6). Bandung: Tarsito. 